\title{
Bazzania scalaris sp. nov. (Marchantiophyta: Lepidoziaceae) from Papua New Guinea
}

\author{
David Meagher
}

School of Botany, The University of Melbourne, Victoria 3010

\begin{abstract}
Bazzania scalaris sp. nov. (Marchantiophyta : Lepidoziaceae), a liverwort from the East Sepik District of Papua New Guinea, is described. The unpublished name 'Mastigobryum linearifolium' in Franz Stephani's Icones is recognised as this species.
\end{abstract}

\section{Introduction}

The genus Bazzania Gray comprises leafy liverworts with two rows of lateral leaves inserted incubously on the stem, a row of underleaves on the ventral side of the stem, and minutely leafy ventral flagella arising from the axils of underleaves. The cells in the outer layer of the stem are not differentiated from those of the inner stem. The branches are always of the Frullania-type; that is, the branch replaces the ventral half of a lateral leaf, leaving the other half of the leaf in the branch junction on the dorsal side. In almost all species the branches grow as strongly as the stem from which they arise, so that the branching is distinctly Y-shaped and resembles dichotomous branching. For this reason, such branching is called 'pseudodichotomous'.

The character trilobed lateral leaves is the normal condition in Bazzania, but a small number of bilobed or unlobed species are known. Bilobed species have been placed traditionally in section Bidentatae, which once included species now placed in genus Acromastigum. In that genus each flagellum replaces half an underleaf, the lateral leaves are never trilobed, and the stem in cross-section has an outer layer of enlarged, transparent cells. Other differences are described by Kitagawa and Grolle (1986). Species of both genera were once grouped together in the genus Mastigobryum Gottsche, Lindenb. \& Nees, but most have now been transferred from that genus.

Several bilobed species of Bazzania are known from Asia and South East Asia, and are well documented in the literature (e.g. Meijer 1960, Pócs 1969, Kitagawa \& Kodama 1975, Kitagawa 1980). None has the combination of characters seen in the current species. 
Bazzania scalaris D.Meagher, sp. nov.

Diagnosis. Bazzania foliis suboppositis, subvittatis, asymmetrice oblongis, fragilis, apicibus asymmetrice 2-dentatis et saepe crenulatis; amphigastriis laceratis, plerumque 3-4-lobatis sed cum lobis minoribus additiciis; cellulis folii valde incrassatis et nodulosis; cellulis amphigastriorum similaribus sed minoribus; gynoecia et androecia desunt.

Type: Papua New Guinea, East Sepik: eastern ridge of Sumset (Mount Hunstein), 15 Aug 1966, R.D. Hoogland 11011 \& L.A. Craven. Holotype: CANB 174151. Isotypes: COLO, F, MEL, MELU (the following replicates have not been examined - BM, JE, LAE, L, TNS).

Plants delicate, strongly anisophyllous, forming loose mats on rock. Branching infrequent, pseudodichotomous, the branches of Frullania-type; branch dorsal halfleaf \pm symmetric, narrowly ovate, tapering to an acute, undivided apex; first branch underleaf 2-fid, often with one or two smaller lobes, adjacent to but not connate with the adjacent stem underleaf. Leaves mostly about $1.2-1.6 \mathrm{~mm} \times 0.4-0.6 \mathrm{~mm}$, subopposite to almost alternate, spreading widely whether moist or dry, fragile, often missing or broken; asymmetrically oblong, with arched dorsal and ventral margins that are often crenulate from projecting cell walls, cuticle smooth; subvittate, with a narrow region of distinctly elongate but not wider cells extending almost to the sinus of the lobes; apex not much narrower than the rest of the leaf, consistently 2-fid with widely to narrowly triangular lobes, sinus between lobes lunate to widely angular, margins often crenulate. Cells in mid-leaf mostly $25-35(-60) \times 15-25(-35) \mu \mathrm{m}$, smaller near the margins, \pm in regular longitudinal rows, thick-walled and strongly nodulose, with bulging and often confluent trigones. Oil bodies not seen. Underleaves mostly about $0.4-0.7 \mathrm{~mm} \times 0.4-0.5 \mathrm{~mm}$, narrowly to barely connate with leaves on one side only, lacerate, fundamentally 3-4-lobed but the lobes often further divided and additional smaller lobes always present. Cells of the underleaves similar to those of the leaves but slightly smaller. Flagella few, long and thin, sparsely and minutely leafy. Gynoecia and androecia not seen. Fig. 1.

\section{Discussion}

Of the small number of bilobed Bazzania species known, most have entire or weakly lobed underleaves, and their lateral leaf cells generally have evenly thickened walls and small trigones, or no trigones at all.

Stephani $(1908,1924)$ described a small number of bilobed Bazzania and Mastigobryum species from South East Asia and Australasia, and illustrated them in his unpublished Icones (Stephani 1985). However, not all the taxa illustrated in the Icones were published by Stephani, including one (no. 6857) labelled 'Mastigobryum linearifolium St. nsp, Nova Guiniae, Ledermann legit' and annotated 'Cellulae foliarum apice 18/18 $\mu$ parietibus validus, basales $18 / 36 \mu$ trigonis majusculis acutis'. I am quite sure that this illustration represents $B$. scalaris, but as a description was never published the name 'Mastigobryum linearifolium' is not valid. Ledermann's herbarium is no longer in Genéve (G), and Kitagawa (1980) noted that Grolle believed it to have been burned in the destruction of the Berlin-Dahlem Herbarium during the Second World War. It is not yet clear whether any of Ledermann's collection of bryophytes from New Guinea survived. 


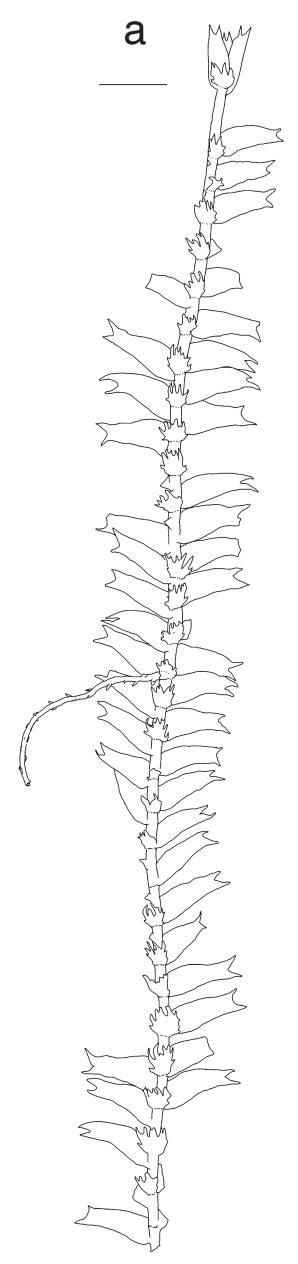

b
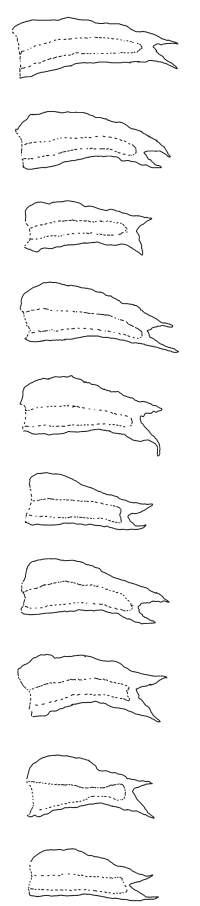

Mow

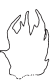

NMy

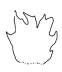

$\{m\}$
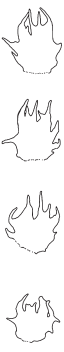

$\{$ sip

f

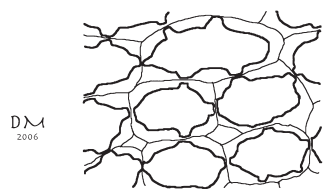

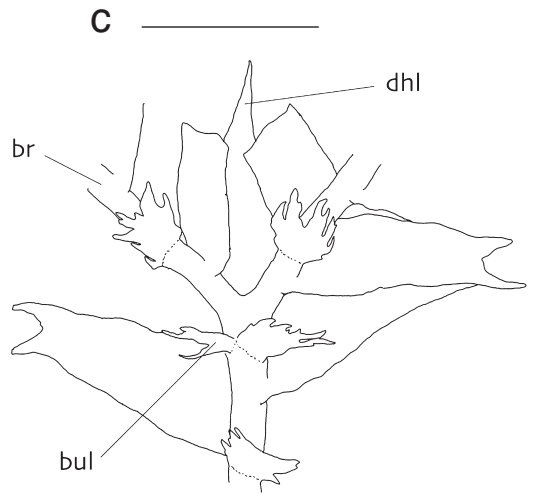

d
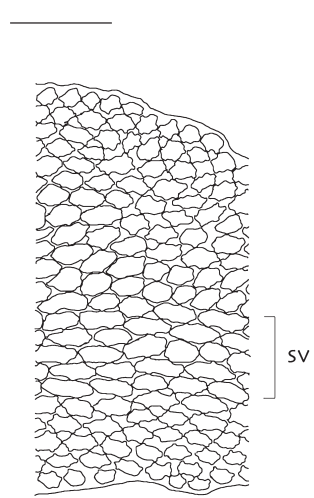

e

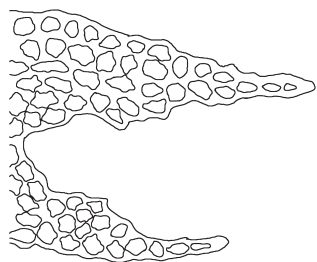

Fig.1. Bazzania scalaris sp. nov. a, ventral view of portion of moist plant; $\mathbf{b}$, lateral leaves and underleaves; c, branching, showing branch (br), first branch underleaf (bul) and dorsal half-leaf (dhl) behind two fractured leaves; d, cells in mid-leaf, showing subvitta (sv); e, cells in leaf apex; f, detail of cells in mid-leaf.

Scale bars: $\mathrm{a}-\mathrm{c}=1 \mathrm{~mm}, \mathrm{~d}, \mathrm{e}=100 \mu \mathrm{m}, \mathrm{f}=50 \mu \mathrm{m}$. 


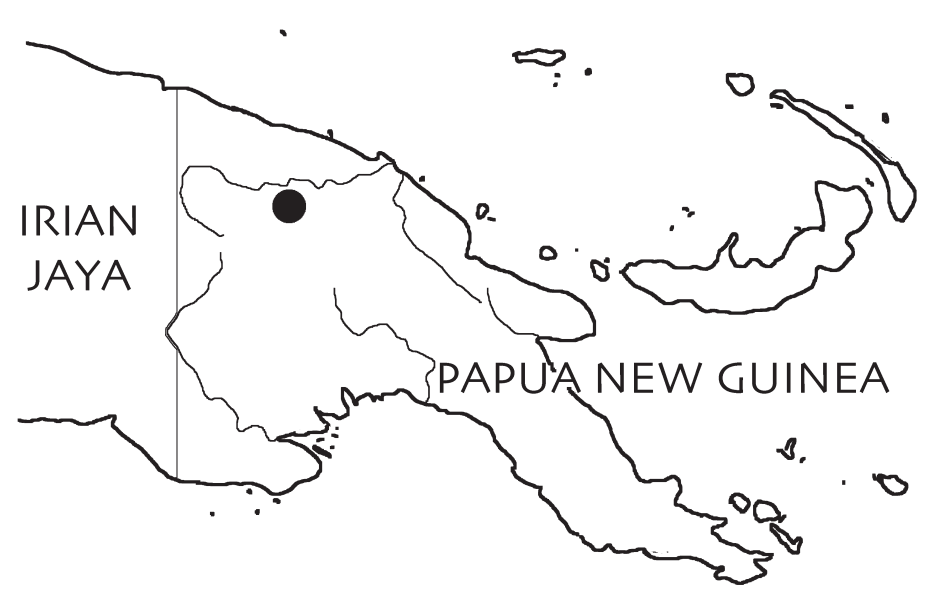

Fig. 2. Type locality (solid circle) of Bazzania scalaris.

Significant studies and reviews of the genus Bazzania have also been undertaken for South East Asia and Melanesia by Evans (1933), Grolle (1968, 1972), Herzog (1931, 1949, 1953), Kitagawa (1972, 1973, 1979, 1980), Meijer (1960) and Tixiér (1985), and for other nearby and distant regions of the world, e.g. Engel and Merrill (1994), Grolle and Schultze-Motel (1973), Hattori and Mizutani (1958), Jones (1975), Long and Grolle (1990), Mizutani (1967), Pócs (1969), Scott (1985).

Among the hundreds of species reported and described, only Bazzania bhutanica N.Kitag. \& Grolle closely resembles the present species. However in that species, from Bhutan in the Himalaya, the cuticle is strongly asperous and often coarsely verruculose, the cells of the lateral leaves have evenly thickened walls and indistinct trigones, and the lobes of the lateral leaves are only weakly spreading. Furthermore, the leaves are much shorter and more or less contiguous to slightly imbricate (Kitagawa \& Grolle 1986). Of the other Asian and Australasian Bazzania species with similar leaves, B. linearis Herzog, B. bicrenata N.Kitag., B. bilobata N.Kitag., B. cadens N.Kitag. and B. distans (Nees) Trevis., all have unlobed or weakly lobed underleaves, and all but the last have an asperous or verruculose cuticle on the lateral leaves (Herzog 1949; Kitagawa 1967, 1980). B. friabilis N.Kitag. \& T.Kodama also has a distinctly verrucose cuticle and the margins of the leaves are quite crenulate, and B. pseudovittata N.Kitag. \& T.Kodama has a very strongly asperous cuticle that gives the plant an overall frosty appearance, very weakly lobed leaves, and very weakly dentate underleaves (Kitagawa \& Kodama 1975).

Bazzania scalaris is known at present only from the type collection (Fig. 2), but no doubt will turn up elsewhere. The specific epithet refers to the ladder-like appearance of intact shoots.

\section{Acknowledgments}

Many thanks are due to Dr Bill Weber (COLO) for providing a number of interesting specimens from New Guinea, among which this species was found. Thanks also to Nic Middleton and Kathy Vohs (MELU) for organising loans and laboratory facilities, and to Dr Elizabeth Brown (NSW) for correcting the original manuscript. 


\section{References}

Arnell S (1963) Hepaticae of South Africa. (Swedish Natural Science Research Council: Stockholm)

Engel JJ \& Merrill, GLS (1994) Studies of New Zealand Hepaticae. 8-13. Bazzania and Acromastigum. The Bryologist 97(3): 313-320.

Engel JJ \& Schuster RM (1980) Studies of New Zealand Hepaticae. 1-6. Brittonia 40(2): 200-207.

Evans AW (1933) ['1932'] Some representative species of Bazzania from Sumatra. Papers of the Michigan Academy of Science, Arts and Letters 17: 69-118.

Fulford MH (1963) ['1962'] Manual of the leafy Hepaticae of Latin America-Part I. Memoirs of the New York Botanical Gardens 2(1): 1-172.

Grolle R (1968) Lebermoose aus Neuguinea. 7. Vierte Fundliste. Journal of the Hattori Botanical Laboratory 31: 1-12.

Grolle R (1972) Bazzania in Europa und Macronesien. Zur Taxonomie und Verbreitung. Lindbergia 1: 193-204.

Grolle R and Schultze-Motel, W (1973) Vorläufiges Verzeichnis der Lebermoose von Samoa. Journal of the Hattori Botanical Laboratory 36: 75-89.

Herzog, T (1931) II. Hepaticae. In Winkler H., Borneo-Pflanzen. Mitteilungen aus den Institut für allgemeine Botanik in Hamburg 7(3): 182-216.

Herzog T (1949) Hepaticae Borneenses (Oxford University Expedition to Sarawak, 1932). Transactions of the British Bryological Society 1(3): 275-326.

Herzog T. (1953) Lebermoose aus Neukaledonien gesammelt von Dr. O.H. Selling. Arkiv för Botanik (ser. 2, band 3) 3: 43-61.

Hodgson EA (1954) New Zealand Hepaticae (Liverworts)—VIII. A review of the New Zealand species of the genera Bazzania and Acromastigum. Transactions of the Royal Society of New Zealand 82(1): 7-24.

Jones EW (1975) African Hepatics XXVII. Bazzania. Journal of Bryology 8: 71-75.

Kitagawa N (1967) Studies on the Hepaticae of Thailand I. The genus Bazzania, with general introduction. Journal of the Hattori Botanical Laboratory 30: 248-270.

Kitagawa N (1972) Notes on little-known species of Hepaticae, 1-25. Journal of the Hattori Botanical Laboratory 36: 444-454.

Kitagawa N (1973) Miscellaneous notes on little-known species of Hepaticae, 26-50. Journal of the Hattori Botanical Laboratory 37: 263-273.

Kitagawa, N (1979) Studies on Asian species of Bazzania, Hepaticae, II. Bulletin of the Nara University of Education 28(2): 71-83.

Kitagawa N (1980) New Guinean species of the genus Bazzania, I. Journal of the Hattori Botanical Laboratory 47 : $127-143$.

Kitagawa N \& Grolle R (1986) A new Acromastigum-like species of Bazzania S. Gray from Bhutan. Journal of the Hattori Botanical Laboratory 61: 269-272.

Kitagawa N \& Kodama T (1975) Two new species of Bazzania with an unusual habitat in Sabah (North Borneo). Journal of the Hattori Botanical Laboratory 61: 269-272.

Long DG and Grolle R (1990) Hepaticae of Bhutan. II. Journal of the Hattori Botanical Laboratory 68: 381-440.

Meijer W (1960) Note on the species of Bazzania (Hepaticae) mainly of Java. Blumea 10(2): 367-366.

Mizutani M (1967) Studies of the Himalayan species of Bazzania. Journal of the Hattori Botanical Laboratory 30: 71-90.

Pócs, T (1969) A short survey of the Bazzania of North Viet-Nam. Journal of the Hattori Botanical Laboratory 32: 79-94.

Pócs T (1994) Taxonomic results of the BRYOTROP expedition to Zaire and Rwanda. 27. Lepidoziaceae, II. Tropical Bryology 9: 123-130. 
Scott GAM (1985) Southern Australian Liverworts. Flora and Fauna Bulletin 2. (AGPS: Canberra)

Stephani F (1908) Species Hepaticarum, vol. 3. (George \& Cie: Genéve \& Bale)

Stephani F (1924) Species Hepaticarum, vol. 6. (Université de Genéve: Genéve)

Stephani F (1985) Icones Hepaticarum, microfiche. (International Documentation Company: Leiden)

Tixiér P (1985) A propos du genre Bazzania en Nouvelle-Calédonie. Récoltes de H.S. MacKee. Cryptogamie, Bryologie-Lichénologie 6: 177-180.

Manuscript received 03 January 2006, accepted 16 June 2006 